\title{
Sistem Pakar Tes Kepribadian Menggunakan Metode Naive Bayes
}

\author{
Khalid Aji \\ khalid.aji1996@gmail.com
}

\author{
Jurusan Teknologi Informasi, Program Studi Teknik Informatika, Politeknik Negeri Malang
}

\begin{abstract}
-- generally aims to understand the behavior of human beings. In practice, psychology is still using traditional methods in the process of understanding and studying the psychology of an object. One traditional method that is still used in psychology is by making questionnaires or a series of statements that will be given to the object to be studied and the questionnaires are filled in by each object.

Based on the above problem it is requried to use technology to make applications in the field of psychology, especially in the sub-field of personality where the application uses computer science in the field of Artificial Intelligence, especially in the branch of the expert system to help classify one's personality by using the Naive Bayes method. This method has a better level of accuracy compared to other classification models. The Naive Bayes method is an effective and efficient classification method because the classification process works independently on each feature of the object to be classified.

Based on the results of system testing comparison using the Naive Bayes method with 100 learning data and testing 10 data testing, the comparison for expert system tests has a $70 \%$ accuracy result. Based on research, the results show the method used well for classification to determine the Introvert or Extroverted personality. In conclusion, the more data used to eat the greater the accuracy value.
\end{abstract}

Intisari -- Ilmu Psikologi merupakan disiplin ilmu yang secara umum bertujuan untuk memahami perilaku sesama manusia. Dalam prakteknya ilmu psikologi sebagian besar masih menggunakan cara-cara dan metode lama dalam proses memahami dan mempelajari ilmu psikologi suatu objek. Salah satu metode lama yang masih digunakan dalam ilmu psikologi yakni dengan cara membuat lembaran-lembaran kuisioner atau serangkaian pernyataan yang akan diberikan kepada objek yang akan dipelajari lalu kuisioner-kuisioner tersebut diisi oleh masing-masing objek.

Melihat hal tersebut perlu pemanfaatan teknologi untuk membuat aplikasi bidang psikologi, khususnya pada sub bidang kepribadian dimana aplikasi tersebut menggunkan pengetahuan komputer dibidang kecerdasan buatan khususnya cabang sistem pakar untuk membantu klasifikasi kepribadian seseorang dengan menggunkana metode Naive Bayes. Sebab, metode ini mempunyai tingkat akurasi yang lebih baik dibandingan model klasifikasi lainnya. Metode Naive Bayes merupakan salah satu metode klasifikasi yang efektif dan efisien karena proses pengklasifikasiannya bekerja secara independen pada setiap fitur objek yang akan diklasifikasi.

Berdasarkan hasil perbandingan pengujian sistem dengan menggunakan metode Naive Bayes dengan 100 data learning dan menguji 10 data testing, perbandingan untuk uji sistem pakar memiliki hasil akurasi 70\%. Berdasarkan penelitian yang dilakukan hasil akurasi menunjukkan bahwa metode yang digunakan cukup baik untuk klasifikasi menentukan jenik kepribadian Introvert atau Ekstrovert. Dapat disimpulkan semakin banyak data yang digunakan maka semakin besar pula nilai akurasinya.

Kata kunci : Tes Kepribadian, Sistem Pakar, Metode Bayes.

\section{PENDAHULUAN}

Ilmu Psikologi merupakan disiplin ilmu yang secara umum bertujuan untuk memahami perilaku sesama manusia [1]. Dalam praktiknya bahwa ilmu psikologi sebagian besar masih menggunakan cara-cara dan metode lama dalam proses memahami dan mempelajari sisi psikologis suatu objek. Salah satu metode lama yang masih digunakan dalam ilmu psikologi yakni dengan cara membuat lembaran-lembaran questioner atau serangkaian pertanyaan yang akan diberikan kepada objek yang akan dipelajari, lalu questioner-questioner tersebut diisi oleh masing-masing objek [2]. Manusia mempunyai karakter yang berbeda- beda dan unik. Karakter atau juga disebut sebagai kepribadian bisa dipelajari dan memiliki kesamaan antara orang satu dengan yang lainnya. Fungsi dari mengetahui tipe kepribadian atau karakter diri adalah [3] untuk mengoptimalkan perubahan diri ke arah yang lebih baik dan positif[3][4].

Psikologi tidak hanya mempelajari pikiran, namun juga mempelajari hubungan antara pikiran dan pengaruhnya terhadap perilaku, sifat [5], kemampuan belajar dan kognitif, kemampuan motorik, dan fungsi manusia secara keseluruhan, Psikolog ditemukan pada beragam industri, tidak hanya terbatas pada pelayanan kesehatan, pendidikan, bisnis, umumnya membantu bagian sumber daya manusia [6]. Beberapa di antaranya memutuskan untuk menjadi psikometris. Setelah mendapatkan gelar sarjana atau pascasarjana, mereka dapat merancang, mengevaluasi, mengubah, dan menganalisa beragam tes untuk melakukan 
pengukuran. Seperti psikiater, psikolog terutama psikolog klinis, dapat mendiagnosa gangguan berdasarkan perilaku pasien, sifat, dan performa tes termasuk komunikasi verbal dan nonverbal, seperti kontak mata [2]. Mereka juga memberikan resep obat Selain terapi-terapi yang diakui untuk memperbaiki, mengendalikan, dan mencegah penyakit mental. Salah satu metode lama yang masih digunakan dalam ilmu psikologi yakni dengan cara membuat lembaran-lembaran questioner atau serangkaian pertanyaan yang akan diberikan kepada objek yang akan dipelajari, lalu questioner-questioner tersebut diisi oleh masing-masing objek.

Melihat hal tersebut perlu pemanfaatan teknologi terlibat untuk membuat aplikasi bidang psikologi, khususnya pada sub bidang kepribadian dimana aplikasi tersebut menggunakan pengetahuan komputer dibidang kecerdasan buatan khususnya cabang sistem pakar yang dapat mengatasi hal-hal tersebut dan juga dapat digunakan sebagai penunjang dalam bidang ilmu psikologi dan dapat digunakan bagi keperluan masyarakat dan individu pada umunya.

\section{METODOLOGI PENELITIAN}

Sistem Pakar Analisis Kepribadian Diri dengan Metode Bayes disusun oleh dua bagian utama, yaitu lingkungan pengembangan dan lingkungan konsultasi. Lingkungan pengembangan sistem pakar digunakan untuk membangun dan memasukkan pengetahuan pakar ke dalam basis pengetahuan, lingkungan konsultasi digunakan oleh pengguna yang bukan pakar dalam memperoleh pengetahuan pakar dan nasehat pakar. Gambar 1 merupakan ilustrasi dari gambaran rancangan sistem yang dibuat.

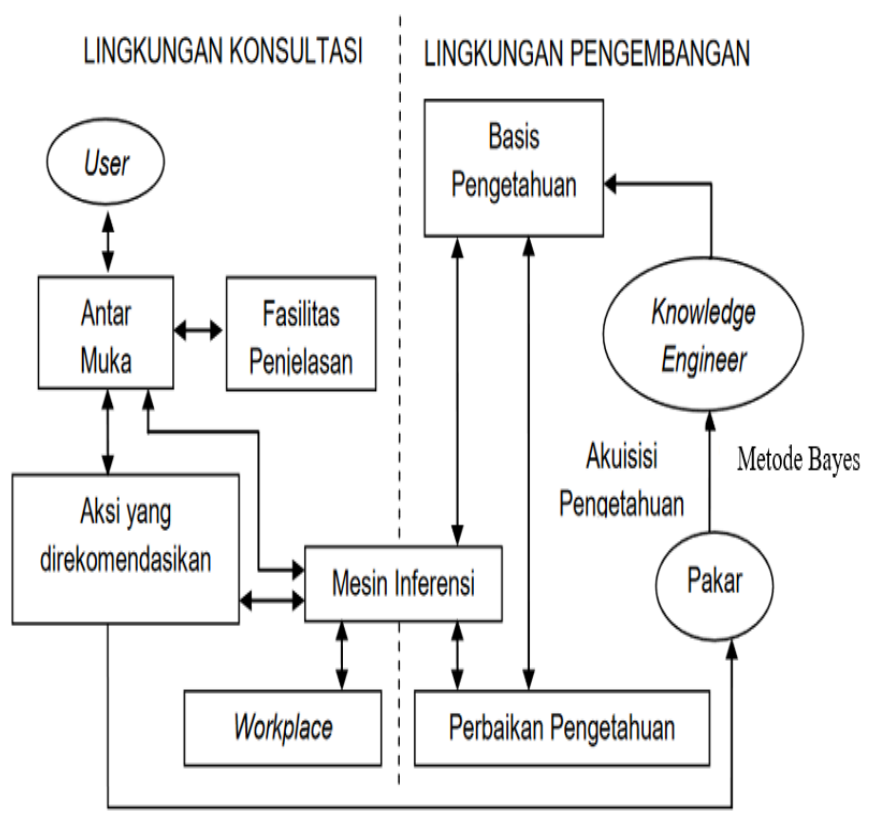

Gambar 1. Alur Sistem

\subsection{Flowchart}
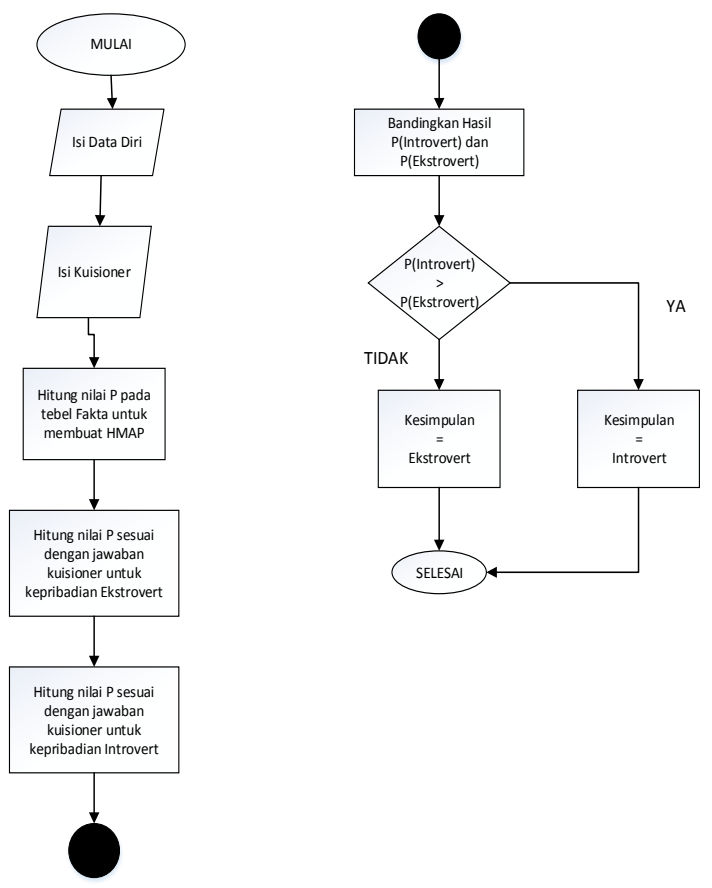

Gambar 2. Flowchart Sistem

Langkah pertama adalah mengisi data diri pada aplikasi Tes Keprribadian, setelah itu dilanjutkan mengisi kuisioner tentang kepribadian Introvert dan Ekstrovert, kemudian program mulai menghitung nilai $\mathrm{P}$ pada tabel fakta untuk membuat HMAP (Hypothesis Maximum Appropri Probability). Setelah itu menghitung nilai P sesuai dengan jawaban kuisioner unutk kepribadian Introvert/Ekstrovert, lalu program akan membandingkan hasil dari perhitungan nilai dari kepribadian User, apakah termasuk dalam kategori Introvert atau Ekstrovert, lalu program mengambil kesimpulan jika nilai Introvert lebih besar dari nilai Ekstrovert maka dapat dikatakan User memiliki kepribadian Introvert. Apabila lebih kecil dari introvert maka kepribadian User adalah Ekstrovert.

\subsection{Analisis Kebutuhan}

Didalam analisis kebutuhan ini merupakan proses mengumpulkan informasi kebutuhan sistem atau perangkat lunak. Untuk membuat aplikasi ini peneliti membutuhkan minimal spesifikasi hardware dan software sebagai berikut:

- Processor :Intel(R) Core(TM) i3 M430 2,27GHZ

- RAM :2 GB

- Harddisk : $500 \mathrm{~GB}$

- Software : Mozilla Firefox,

MySQL,XAMPP, Notepad++. 


\subsection{Analisa Sistem}

Aplikasi Tes Kepribadian untuk mengetahui kepribadian sesorang. Merupakan aplikasi yang dibuat dan dirancang sebagai alat mengetahui kepribadian seseorang serta memberikan informasi kepada user bagaimana berprilaku dikehidupan sosial dengan kepribadian yang dimiliki.

Diharapkan dapat menjadi salah satu alternatif bantuan bagi orang yang ingin mengetahui informasi mengenai kepribadian berdasarkan kuisioner keribadian. Sehingga orang dapat mengetahui kepribadian apa yang dimiliki nya.

\subsection{Coding dan Testing}

Pada tahap ini desain sistem menjadi sebuah program yang siap untuk dioperasikan dan setelah pengkodean selesai maka akan dilakukan percobaan terhadap system yang telah dibuat. Tujuan testing adalah menemukan kesalahan - kesalahan terhadap system tersebut dan kemudian bisa diperbaiki.

\section{HASIL DAN PEMAHASAN}

\section{A. Pengujian Program}

Pada Tahap pengujian program ini kegiatan yang dilakukan yaitu sistem yang sudah dibuat sebelumya akan diimplementasikan dan digunakan oleh user.

\begin{tabular}{|c|c|c|c|c|}
\hline \multicolumn{5}{|c|}{ a. Pengujian Halaman Admin, Login } \\
\hline \multicolumn{3}{|c|}{ Pengujian } & $\begin{array}{c}\text { Hasil yang } \\
\text { Diharapkan }\end{array}$ & $\begin{array}{c}\text { Hasil } \\
\text { Pengujian }\end{array}$ \\
\hline \multicolumn{3}{|c|}{$\begin{array}{c}\text { Data username, } \\
\text { password dan level } \\
\text { sesuai }\end{array}$} & $\begin{array}{c}\text { Menuju ke } \\
\text { Halaman Rekam } \\
\text { Medis } \\
\end{array}$ & Sesuai \\
\hline \multicolumn{4}{|c|}{$\begin{array}{c}\text { ISIKAN USERNAME DAN } \\
\text { PASSWORD }\end{array}$} & \\
\hline & & \multicolumn{2}{|l|}{ |User ID } & \\
\hline & & \multicolumn{2}{|c|}{ Password } & \\
\hline & & \multicolumn{2}{|r|}{ PLOGIN } & \\
\hline nan & sia & Jaris latarin & Nillit & |rasi \\
\hline mi & 0 & Perequan & 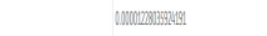 & gssonet \\
\hline ii & i & Premonn & 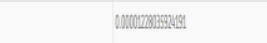 & Essoust \\
\hline in & y & Peremon & 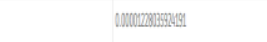 & dssonet \\
\hline iil & " & Premention & 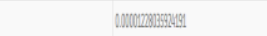 & Estant \\
\hline III & "1 & Premonn & 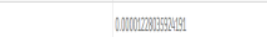 & Esconest \\
\hline
\end{tabular}

Tabel 1. Pengujian Login

\begin{tabular}{|c|c|c|c|c|}
\hline No & Nama & $\begin{array}{c}\text { Hasil } \\
\text { Program }\end{array}$ & $\begin{array}{c}\text { Hasil } \\
\text { Pakar }\end{array}$ & $\begin{array}{c}\text { Sesuai/Tidak } \\
\text { Sesuai }\end{array}$ \\
\hline 1 & Jarir & Ekstrovert & Introvert & Tidak Sesuai \\
\hline 2 & Ulvi & Introvert & Introvert & Sesuai \\
\hline 3 & Dini & Ekstrovert & Introvert & Tidak Sesuai \\
\hline 4 & Nita & Introvert & Introvert & Sesuai \\
\hline 5 & Rahma & Ekstrovert & Ekstrovert & Sesuai \\
\hline 6 & Gading & Ekstrovert & Ekstrovert & Sesuai \\
\hline 7 & Hidayah & Ekstrovert & Ekstrovert & Sesuai \\
\hline 8 & Prawira & Ekstrovert & Ekstrovert & Sesuai \\
\hline 9 & Ilham & Ekstrovert & Ekstrovert & Sesuai \\
\hline 10 & Hatma & Ekstrovert & Introvert & Tidak Sesuai \\
\hline
\end{tabular}

Pada bagian ini adalah pembahasan penggunaan metode pada sistem pakar Tes Kepribadian Menggunakan Metode Naive Bayes. Setelah dilakukan pengujian terhadap 10 Orang data testing dengan 47 data Kuisioner pada sistem pakar Tes Kepribadian Menggunakan Metode Naive Bayes dan dibandingkan dengan hasil pada pakar dengan metode naïve bayes untuk menentukan kepribadian

Berdasarkan hasil perbandingan pengujian sistem dengan metode Naïve Bayes pada tabel 5.3 Dengan 100 data learning menguji 10 data testing perbandingan uji sistem dengan pakar memiliki hasil sebagai berikut:

a. Data yang sesuai ada 7 data dari 10 data sampel.

$7 / 10 \times 100 \%=70 \%$

b. Data yang tidak sesuai ada 3 data dari 10 data sampel.

$3 / 10 \times 100 \%=30 \%$

\section{B. Pemeliharaan}

Merupakan tahap akhir dari pembangunan sebuah sistem. Kegiatan ini dilakukan bertujan untukmengoreksi kesalahan pada perangkat baik itu software ataupun hardware.

\section{KESIMPULAN DAN SARAN}

Sistem Pakar tes Kepribadian menggunakan Metode Bayes ini masih dapat dikembangkan, sehingga tingkat akurasi dan komputasi yang diperoleh bisa lebih baik. Oleh karena itu, adapun saran untuk pengembangan penelitian selanjutnya yaitu: Optimasi sistem lebih ditingkatkan ketika memproses pencarian jawaban.

\section{DAFTAR PUSTAKA}

[1] Abu Bakar MS, "PSIKOLOGI TRANSPERSONAL; Mengenal Konsep Kebahagiaan dalam Psikologi Oleh Abu Bakar MS," vol. 8, no. 2, pp. 162-180, 2018.

[2] A. R. Wardhani and C. B. Santoso, "METODE PSIKOLOGIS TERHADAP INTENSI KELUAR DENGAN KOMITMEN AFEKTIF SEBAGAI VARIABEL," vol. 4, no. 3, pp. 464-473, 2018.

[3] K. S. Devi and K. R. Suwena, "Analisis Kepribadian Psikologis Dan Faktor Organisasi yang Berpengaruh di Kinerja Karyawan,” vol. 5, no. 1, pp. 24-33, 2018. 
[4] A. Y. Rahman, M. Sa'adah, F. W. Setiawan, and E. Supriyanto, "Vice Presidential Election Prediction Period 2019- 2024 using Simple Additive Weighting," pp. 5660, 2018.

[5] H. Effendi, Warjio, and Kariono, "Pengaruh FaktorFaktor Motivasi Dari Finansial, Psikologi, Dan Sosial Terhadap Prestasi Kerja Pegawai," vol. 7, no. 1, pp. 1732, 2017.

[6] A. Y. Rahman, M. Sa'adah, F. W. Setiawan, A. L. Hananto, and E. Supriyanto, "Access Level File using Simple Additive Weighting,” pp. 62-66, 2018. 